\title{
PROTECTIVE EFFECT AND MECHANISM OF SCHISANDRA CHINENSIS EXTRACT ON RETINAL PHOTORECEPTOR CELL INJURY
}

\author{
CAIHAN YU ${ }^{1 \#}$, XINGGUANG HE ${ }^{1 \#}$, XUDONG LV $^{1}$, LANLAN GONG $^{1}$, XINCHAO CHENG $^{1}$, \\ JIE YANG ${ }^{1}$, MENGNAN ZHU ${ }^{1}$, ZHINONG WU ${ }^{2 *}$ \\ ${ }^{I}$ Department of Ophthalmology, Xianning Central Hospital, The First Affiliated Hospital of Hubei University of science and \\ technology, Xianning, 437100, Hubei, China \\ ${ }^{2}$ Department of Clinical Laboratory, Xianning Central Hospital, The First Affiliated Hospital of Hubei University of science \\ and technology, Xianning, 437100, Hubei, China
}

*corresponding author: wuzhinongyisheng@163.com

\#Authors with equal contribution.

Manuscript received: July 2020

\begin{abstract}
This study aimed to investigate the protective effect of Schisandra chinensis extract on retinal photoreceptor cell damage and the underlying mechanism in an intend to provide the pharmacodynamic basis for Schisandra chinensis compatibility in the treatment of retinal degenerative diseases. Forty-two male mice were randomly divided into six groups: the control group, the light exposure group (6/12/24/36 h) and the Schisandra group (received $400 \mathrm{mg} / \mathrm{kg}$ bw twice a day Schisandra extract ip for 1 day before the experiment and during the exposure to the light). The retinal light injury model was obtained by exposure the animals to light for 36 hours. The expression of Poly [ADP-ribose] polymerase 1 (PARP-1), Fos-related antigen-2 (Fra-2) and apoptosis-related proteins as cytochrome c (Cyt-C), BCL2 Associated X (Bax), B-cell lymphoma 2 (Blc-2), B-cell lymphomaextra-large (BCL-XL) were detected by Western blot. The results showed that after 12 hours of visible light exposure, the retina of mice was damaged. At the molecular level, the expressions of Cyt-C and Bax, significantly increased after $12 \mathrm{~h}$ of light exposure while the expression of Blc-2, BCL-XL significantly decreased. The levels of PARP-1 and Fra- 2 in mouse retina increased significantly from $6 \mathrm{~h}$ to $36 \mathrm{~h}$ of light exposure. The structure and function of retina of mice treated with Schisandra chinensis extract intervention were complete and normal. It was observed a significant decrease in the Cyt-C and Bax levels and a significant increase in the Bcl-2 and Bcl-xL compared with the group exposed 36h to light along with a significant decrease in the PARP-1 and Fra-2 protein levels with no apoptosis in the outer nuclear layer of the retina. This study showed that Schisandra chinensis extract has a significant therapeutic effect on preventing the photoreceptor cell degeneration induced by light injury by modulating the expression of PARP-1, Fra-2 proteins implicated in the regulation of apoptosis in light-induced retinal injury.
\end{abstract}

\section{Rezumat}

Acest studiu a avut ca scop investigarea efectului protector al extractului de Schisandra chinensis asupra deteriorării celulelor fotoreceptoare ale retinei precum și a mecanismului de acțiune, cu scopul de a stabili o bază farmacodinamică privind utilitatea acestei plante în tratamentul bolilor degenerative ale retinei. Patruzeci și doi de șoareci de sex masculin au fost împărțiţi în mod aleatoriu în șase grupuri: grupul martor, grupul de expunere la lumină (6/12/24/36h) şi grupul Schisandra (care a primit de două ori pe zi $400 \mathrm{mg} / \mathrm{kg}$ corp extract de Schisandra ip cu o zi înainte de experiment și în timpul expunerii la lumină). Modelul de leziune a luminii retiniene a fost obținut prin expunerea animalelor la lumină timp de 36 de ore. S-a evaluat expresia proteinelor PARP-1, Fra-2, Cyt-C, Bax, Blc-2 prin tehnica Western blot. Rezultatele au arătat că, după 12 ore de expunere la lumină vizibilă, retina şoarecilor a fost deteriorată. La nivel molecular, expresia Cyt-C şi Bax a crescut semnificativ după 12 ore de expunere la lumină, în timp ce expresia Blc-2, BCL-XL a scăzut semnificativ. Nivelurile proteinelor PARP-1 și Fra-2 în retină au crescut semnificativ de la 6h la 36h de expunere la lumină. Structura și funcția retinei şoarecilor trataţi cu extract de Schisandra chinensis a fost normală. S-a observat o scădere semnificativă a nivelurilor de Cyt-C și Bax și o creștere semnificativă a Bcl-2 și Bcl-xL comparativ cu grupul expus la lumină timp de36h precum și cu o scădere semnificativă a proteinelor PARP-1 și Fra-2 în stratul nuclear exterior al retinei.

Keywords: Schisandra chinensis, retinal degeneration, photoreceptor cells, PARP-1, Fra-2

\section{Introduction}

Medicinal plants represent nowadays a relevant and reliable source of active principles that are used in order to prevent, ameliorate or treat wide range of pathologies $[1,2]$. Retinal light damage is the damage of retina caused by excessive light exposure. The cornea and lens of the eye protect the human retina from the damage caused by the short wavelength radiation below $400 \mathrm{~nm}$ [3]. The sunlight is composed of many electro-magnetic waves of different wavelengths. The size of light wavelength can affect the energy of photons [4]. Light with a wavelength lower 
than $510 \mathrm{~nm}$ may be directly related to retinal light damage. The shorter the wavelength, the greater the damage. Ultraviolet light is the main cause of retinal damage [5]. Red light and visible light can all reach the retina through the refractive stroma of the eye tissue, leading to light-induced retinal damage [6]. Up to now, the mechanism of retinal light injury has not been fully elucidated, but experts and researchers have carried out in-depth exploration and made great progress [7]. In the process of retinal damage, there were observed changes and remodelling in neurons and glial cells that lead to retinal structure changes and retinal damage. The process of retinal remodelling is progressive starting with the apoptosis of photoreceptor cells, including cone cells and rod cells that lead to the destruction of the normal structure of the retina, and finally remodelling of the neuroretina, apoptosis of retinal ganglion cells, and activation, proliferation and fibrosis of the optic glial cells [8]. Retinal remodelling is associated with apoptosis of retinal cells, destruction of retinal spatial structure, the disappearance of retinal structural stability, synaptic connection and reconstruction of the transduction pathway [9]. In the process of vision formation, visual signals are transmitted from all directions of the retina to the retinal ganglion cells of the optic papilla, and the axon fibres of the retinal ganglion cells transmit the signals to the visual centre. The apoptosis of the retinal ganglion cells is one of the main physiological and pathological characteristics of several ophthalmic diseases [10]. It has been proved that visible light can induce apoptosis of retinal ganglion cells, especially in diabetic, glaucoma induced retinopathy [11] and ischemia-induced neuroretinopathy. Retinal ganglion cells are more vulnerable to visible light stimulation and damage.

Schisandra chinensis is a member of Schisandraceae family, used in the traditional Chinese medicine for its properties that strengthen the body [12]. In this study, we aimed to investigate the mechanism of Schisandra chinensis in protecting from the retinal damage induced by light exposure using a mouse retinal light damage model in order to provide the proof of concept for using this plant in the treatment of retinal light damage.

\section{Materials and Methods}

\section{Animals and groups}

The animal experiment protocol was approved by the Ethical Committee of Xianning Central Hospital, China. Forty-two 8 - 12 weeks old male BALB/c mice, with a weight of $25.2 \pm 3.0 \mathrm{~g}$ were provided by Medical Experimental Animal Center of Guangdong Province. Before the experiment, all mice were acclimatized for one week to the new laboratory conditions: $12 \mathrm{~h}$ light/dark cycle, constant temperature $\left(26^{\circ} \mathrm{C}\right)$ and humidity (40 - 60\%) and had free access to normal animal feed and drinking water. The mice were randomly divided into 6 groups, 7 animals per group: control group, light $6 \mathrm{~h}$ group, light $12 \mathrm{~h}$ group, light $24 \mathrm{~h}$ group, light $36 \mathrm{~h}$ group, Schisandra group. The Schisandra group received $400 \mathrm{mg} / \mathrm{kg}$ Schisandra extract twice per intraperitoneally for 1 day before the experiment and during the $36 \mathrm{~h}$ of exposure to the light. The Schisandra extract was purchased from Xi'an Yuansen Biotechnology Co., Ltd., China. The extract specification provided a composition of Schisandrin B + Schizandrin A + Schizandrin $\geq 3 \%$.

Establishment of a light damage model

A self-made incubator with a length of $1 \mathrm{~m}$, a width of $1 \mathrm{~m}$ and a height of $1 \mathrm{~m}$ is equipped with fluorescent lamps (wavelength $510-560 \mathrm{~nm}$ ) on six sides of the incubator. According to the illuminance meter, the light intensity is 2600 lux. All experimental animals were kept in light for 12 hours and dark environment for 12 hours before modelling, for 10 days. After 10 days acclimatization period, the mice were darkadapted for 24 hours and then moved to the light incubator and exposed to the light for $6,12,24$ and $36 \mathrm{~h}$ respectively, to receive 24 hours of light.

Haematoxylin and eosin (HE) staining and observation on the microstructure of retinal light injury in mice $\mathrm{HE}$ staining and light microscopy was used to observe the histopathological changes of the eyeballs in each group. Extraction and fixation: the eye tissue fixed in $4 \%$ paraformaldehyde (Sigma-Aldrich, USA) was removed under the microscope (Yzzot, Suzhou Medical Equipment Factory, China), the vitreous body and lens were removed, the part of the eyecup was retained, and the eyecup tissue was fixed in $4 \%$ paraformaldehyde for 24 hours. After dehydration with anhydrous ethanol, the tissue was sectioned in slices of $8 \mu \mathrm{m}$ thickness.

HE staining: the slides were stained with haematoxylin for $5 \mathrm{~min}$, washed with distilled water for $1 \mathrm{~min}$, differentiation for $2 \mathrm{~s}$ with $1 \%$ hydrochloric acid ethanol, then treated for 2 min with $1 \%$ ammonia water, washed with distilled water for $1 \mathrm{~min}$, stained for $1 \mathrm{~min}$ with $1 \%$ eosin and finally washed for $5 \mathrm{~min}$ with, distilled water.

Western blot

Using $12.5 \%$ SDS-PAGE gel and a half dry sucking instrument (Bio Rad Laboratory), the proteins were transferred to nitrocellulose membrane (Millipore, Eschborn, Germany) by electricity and incubated overnight at $4{ }^{\circ} \mathrm{C}$ with primary antibodies anti-PARP-1 (Invitrogen-44-698G, USA, 1:1000), Fra-2 (InvitrogenMA5-27192, USA, 1:2000), Cyt-C (Invitrogen-338500, USA, 1:1000), Bax (Invitrogen-33-6400, USA, 1:1000), Blc-2 (Invitrogen-MA5-15046, USA, 1:1000), BCL-XL (Invitrogen-MA5-15142, USA, 1:1000). The second antibody (1:2000) combined with horseradish peroxidase (HRP) was added for 2 hours and washed for 3 times. Amersham enhanced chemiluminescence (ECL, Invitrogen iBright, USA) was used to detect the reaction bands. Amersham scanning imprinted image 
FARMACIA, 2021, Vol. 69, 1

600 scanner (GE Healthcare Life Sciences, USA) was used to quantify the protein band density.

Real time fluorescence quantitative PCR (RT-PCR) RT-PCR was used to detect the expression of PARP-1 and/Fra-2 mRNA in the mouse retina. The total RNA of mouse retina was extracted by Trizol lysate (Invitrogen
TRIzol, USA), and cDNA was synthesized by reverse transcription kit (Takara Bio, Japan). The specific primers for each gene were designed and synthesized by Huada gene company. The nucleotide sequence of the primers is shown in Table I.

Table I

Primer sequence information

\begin{tabular}{lll}
\hline \multicolumn{1}{c}{ Name } & & Primer sequence (5'-3') \\
\hline \multirow{2}{*}{ PARP-1 } & Upstream primers & TCCCAAGGACTCCCTCCGCATGG \\
& Downstream primers & CTTTGCCTGCCACGCCTCCAGCC \\
\multirow{2}{*}{ fra-2 } & Upstream primers & GGATCCGGGAGCTGACAGAGAAG \\
& Downstream primers & GTCGACTTACAGAGCCAGCAGAG \\
\multirow{2}{*}{$\beta$-actin } & Upstream primers & CTTAGTTGCGTTACACCCTTTCTTG \\
& Downstream primers & CTGTCACCTTCACCGTTCCAGTTT \\
\hline
\end{tabular}

Statistical analysis

All data were processed by SPSS 23.0 (IBM, USA). The measured data were expressed as mean \pm standard deviation. The t-test was used for comparison between the two groups and analysis of variance (ANOVA) for comparison of three or more groups. A value of $\mathrm{p}<0.05$ was considered statistically significant.

\section{Results and Discussion}

Damage of mouse retina by light exposure

The HE staining showed that with the prolongation of light exposure time, the retina of mice suffered serious damage after continuous light exposure, with more significant results after $12 \mathrm{~h}$ of exposure.

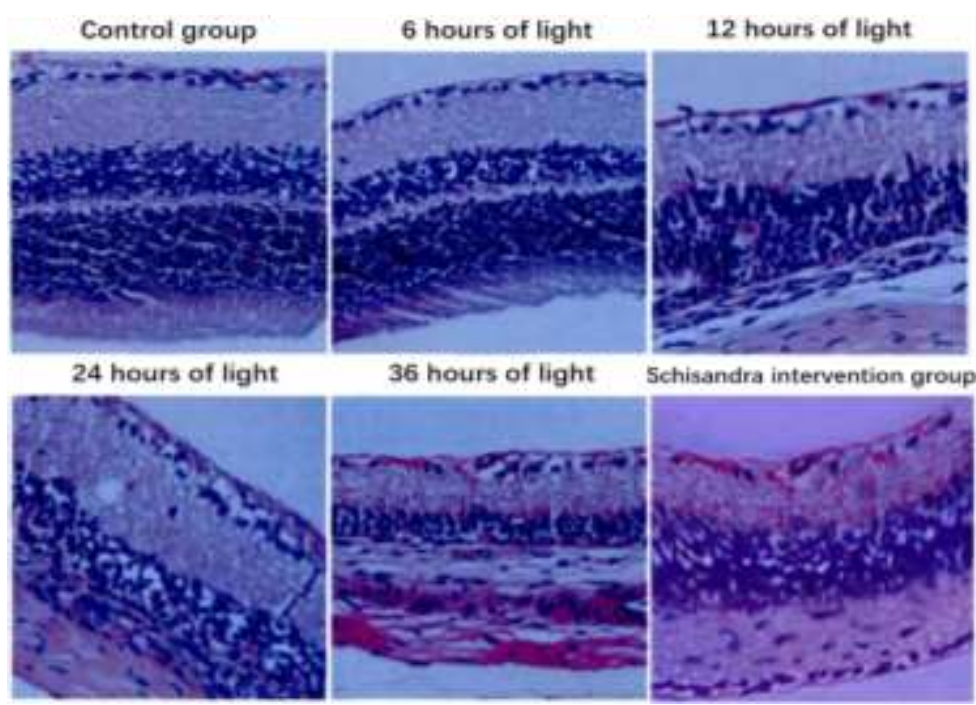

Figure 1.

HE staining was used to observe the damage of retinal tissue structure in mice under continuous light (400X)

The main damage appeared in the nuclear layer and ganglion cell layer, which showed tissue and cell lysis. After exposure to light for 12 hours, the inner and outer nuclear layers of the retina in mice became thinner, tissue dissolution occurred, the outer segments of photoreceptors were disordered, and the ganglion cell layer developed apoptosis. The effects were worsened with the time of exposure. In the control group and Schisandra group, the retina structure was normal, the monolayer was closely arranged, the layers were well anastomosed, and the tissue did not dissolve or fall off obviously (Figure 1).
Expression of apoptosis-related proteins in mouse retina after light exposure

The expression of apoptosis-related proteins Cyt-C, $\mathrm{Bax}, \mathrm{Bcl}-2$ and $\mathrm{Bcl}-\mathrm{xL}$ in the retina of mice is shown in Figure 2. Among the four apoptosis-related proteins, the expression of Cyt-C and Bax increased significantly after 12 hours of light exposure, in a time depending manner ( $p<0.01)$, and the expression of Bcl-2 and Bcl-XL decreased significantly after 24 hours of light exposure in a time depending manner. In Schisandra group, the expression of Cyt-C and Bax significantly decreased compared with the $36 \mathrm{~h}$ light group, while the Bcl-2 and Bcl-xL significantly increased compared with 36 h light group (Figure 2). 

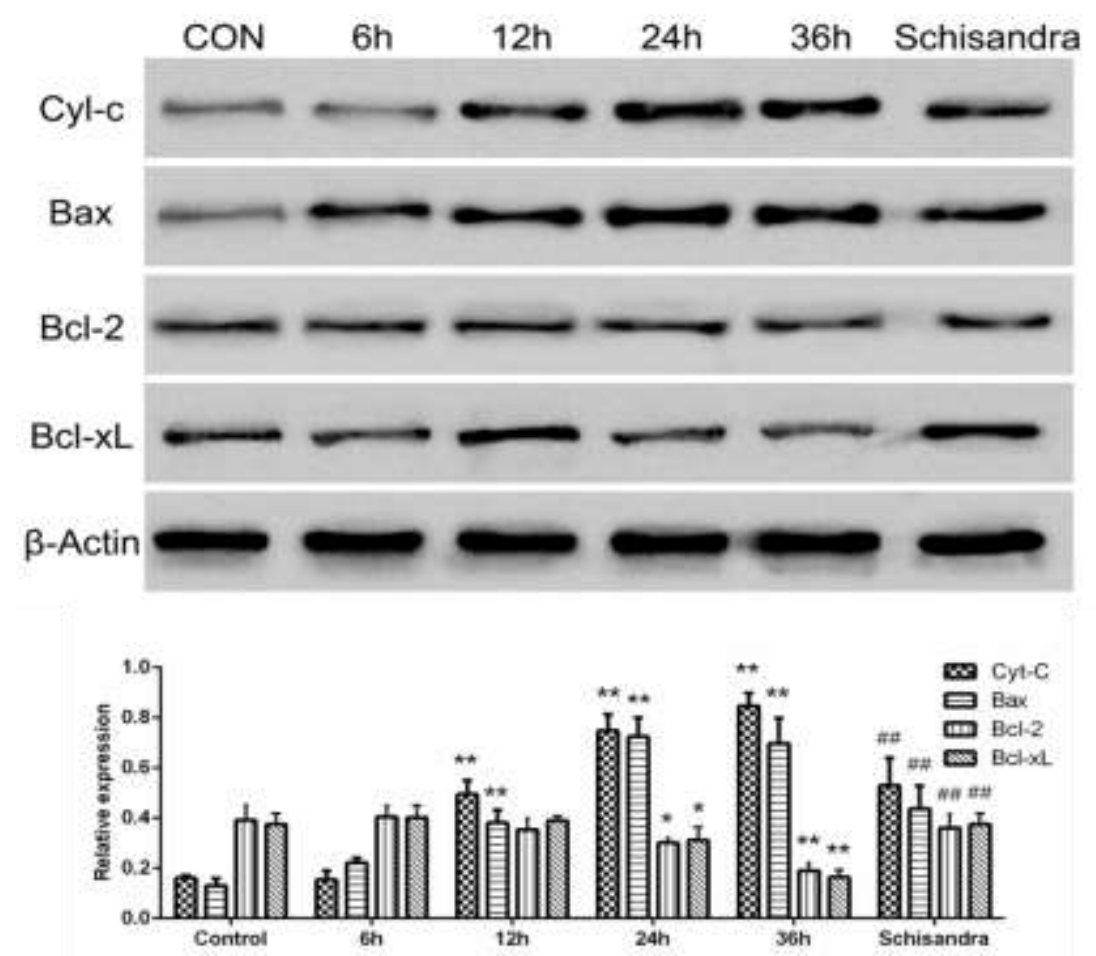

Figure 2.

Relative expression of Cyt-C, Bax, Bcl-2 and Bcl-xL protein in control, $6 \mathrm{~h}, 12 \mathrm{~h}, 24 \mathrm{~h}$ and $36 \mathrm{~h}$ group and

Schisandra intervention group

** vs. the control group, $\mathrm{p}<0.01$; * vs. the control group, $\mathrm{p}<0.05$; \#\# vs. the $36 \mathrm{~h}$ group, $\mathrm{p}<0.01$

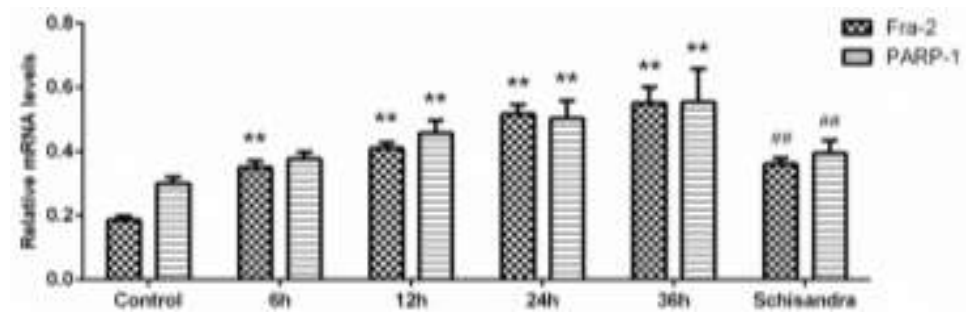

Figure 3.

Fra-2 and PARP-1 mRNA expression levels in retinal tissues of mice detected by fluorescence quantitative PCR ** vs. the control group, $\mathrm{p}<0.01$; * vs. the control group, $\mathrm{p}<0.05$; \#\# vs. the $36 \mathrm{~h}$ group, $\mathrm{p}<0.01$

The mRNA expression level of Fra-2 and PARP-l in mouse optic reticulum

The mRNA expression level of Fra-2 and PARP-1 in the retina of mice significantly increased compared with the control group in a time-dependent manner with the exposure period. The treatment with Schisandra extract significantly decreased the mRNA expression of Fra- 2 and PARP-1 compared with the $36 \mathrm{~h}$ group (Figure 3).

The Protein expression level of Fra-2 and PARP-l in mouse optic reticulum

With the increase of light exposure time, the expression level of Fra-2 and PARP-1 in the retina of mice significant increased compared with the control group $(\mathrm{p}<0.01)$. The Schisandra treatment significantly decrease the Fra-2 and PARP-1 protein expression compared with $36 \mathrm{~h}$ group, with no differences compared with the control group (Figure 4).
The sensitivity of the retina to light signal is the basis of vision formation, but the adaptability of various retinal cells to light intensity is limited. Therefore, when the retina is stimulated by strong light, it will cause the damage of retina tissue structure and cell apoptosis [13]. It has been reported that strong light exposure can cause damage to photoreceptor cells/ retinal pigment epithelial cells, accompanied by local retinal tissue oedema. As an important functional cell in retinal tissue, retinal ganglion cells have been reported to participate in photoreceptor damage induced by light exposure [14]. Besides, when the photoreceptor cells of the retina are damaged and changed, the synapses also undergo reorganization [15]. The reorganization of photoreceptor cells shows that the deep synaptic invagination decreases and the number of connecting bands changes. The presynaptic vesicles of non-apoptotic rod cells contracted from the outer plexiform layer to the outer nuclear layer [16]. At this time, although the 
synaptic vesicles of cone cells are still in the outer plexiform layer, their morphology and the specificity of synaptic connection change. The mechanism of retinal damage caused by light exposure is complex and not fully elucidated.

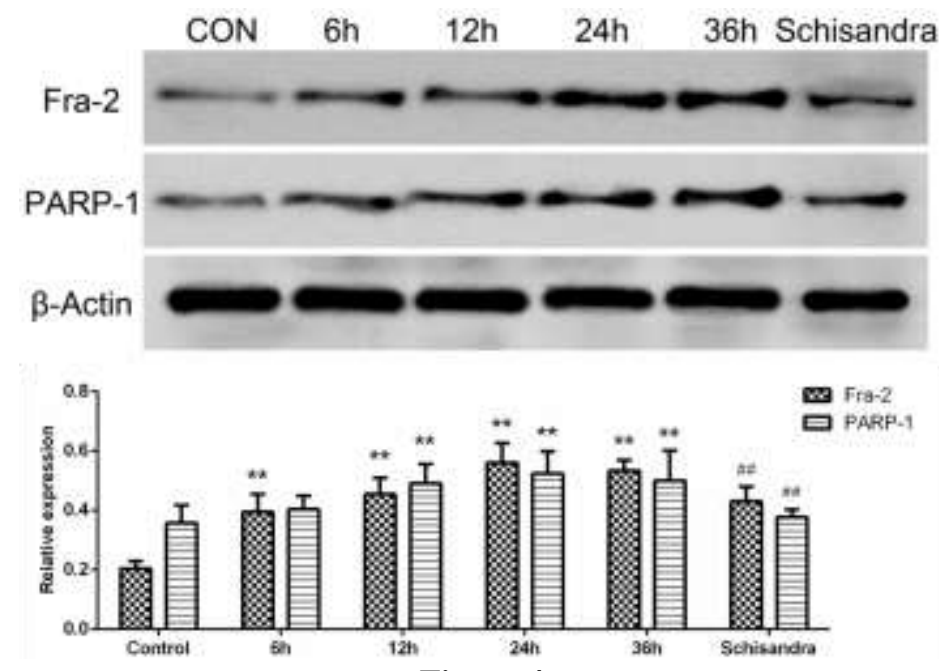

Figure 4.

Fra-2 and PARP-1 protein expression in retinal tissues detected by western blot

** Compared with the control group, $\mathrm{p}<0.01$; * Compared with the control group, $\mathrm{p}<0.05$; \#\# Compared with $36 \mathrm{~h}$ group, $\mathrm{p}<0.01$

In this study, we use a mice model of light retinal damage by exposing the animals for 36 hours to continuous light, and samples were collected after 6, 12, 24 and 36 hours of exposure respectively. The results of HE staining showed that the monolayer of the retina in the normal, non-exposed group was closely arranged, the layers were well fitted, and there was no obvious dissolution or detachment of the retina. After 12 hours of strong light exposure, the retina tissue structure and, the outer ganglion membrane disc of photoreceptor cells was damaged, the inner and outer nuclear layers were thinned, tissue dissolution occurred, the arrangement of photoreceptor cells was disordered, and the ganglion cell layer was apoptotic. Previous studies have shown that the photoreceptor cells of the retina are damaged significantly after strong light exposure, which causes the membrane disc of photoreceptor extracellular node to fall off, and after the damaged retina is repaired, the photoreceptor extracellular node cannot completely regenerate, resulting in irreversible changes of ganglion cells and bipolar cells [17]. We showed the implication of up-regulation of Cyt-C and Bax expression and the down-regulation of Bcl-2 and Bcl-xL in this process along with the upregulation of Fra-2 and PARP-1 expression in the light retinal damage.

The implication of Fra-2 upregulation that determines a significant increase in the expression PARP-1 in the pathogenesis of light-induced retinal damage was previously shown also by Lv and Xing [18].

\section{Conclusions}

In this study, Schisandra chinensis treatment regulates photoreceptor cell damage and protects photoreceptor cells by down-regulating the Cyt-C and Bax levels and up-regulating the Bcl-2 and Bcl-xL levels through Fra-2 down-regulation that inhibits PARP-1 pathway. In conclusion, the Schisandra chinensis extract could be a promising treatment for the light-induced retinal damage. Further clinical studies should be developed in order to confirm these findings.

\section{Conflict of interest}

The authors declare no conflict of interest.

\section{References}

1. Nowak A, Zakłos-Szyda M, Błasiak J, Nowak A, Zhang Z, Zhang B, Potential of Schisandra chinensis (Turcz.) Baill. in human health and nutrition: A review of current knowledge and therapeutic perspectives. Nutrients, 2019; 11(2): 333: 1-20.

2. Xiong Y, Zeng W, Protective effect of ellagic acid in vascular epoxidation damage in a murine model of atherosclerosis. Farmacia, 2019; 67(3): 490-495.

3. Liu H, Tang J, Du Y, Saadane A, Tonade D, Samuels I, Veenstra A, Palczewski K, Kern TS, Photoreceptor cells influence retinal vascular degeneration in mouse models of retinal degeneration and diabetes. Invest Ophthalmol Vis Sci., 2016; 57(10): 4272-4281.

4. Alsaeedi HA, Koh AE, Lam C, Rashid MBA, Harun MHN, Saleh MFBM, Teh SW, Luu CD, Ng MH, Isa HM, Leow SN, Then KY, Bastion MC, Mok PL, Muthuvenkatachalam BS, Samrot AV, Swamy KB, Nandakumar J, Kumar SS, Dental pulp stem cells therapy overcome photoreceptor cell death and protects the retina in a rat model of sodium iodate-induced retinal degeneration. J Photochem Photobiol B., 2019; 198: 111561: 1-8.

5. Terao R, Honjo M, Ueta T, Obinata H, Izumi T, Kurano M, Yatomi Y, Koso H, Watanabe S, Aihara 
M, Light stress-induced increase of sphingosine 1phosphate in photoreceptors and its relevance to retinal degeneration. Int J Mol Sci., 2019; 20(15): 3670: 1-20.

6. Ben M'Barek K, Habeler W, Plancheron A, Jarraya M, Regent F, Terray A, Yang Y, Chatrousse L, Domingues S, Masson Y, Sahel JA, Peschanski M, Goureau O, Monville C, Human ESC-derived retinal epithelial cell sheets potentiate rescue of photoreceptor cell loss in rats with retinal degeneration. Sci Transl Med., 2017; 9(421): eaai7471: 1-12.

7. Wang S, Liu Y, Tan JW, Hu T, Zhang HF, Sorenson CM, Smith JA, Sheibani N, Tunicamycin-induced photoreceptor atrophy precedes degeneration of retinal capillaries with minimal effects on retinal ganglion and pigment epithelium cells. Exp Eye Res., 2019; 187: 107756: 1-10.

8. Zhao L, Li J, Fu Y, Zhang M, Wang B, Ouellette J, Shahi PK, Pattnaik BR, Watters JJ, Wong WT, Guo LW, Photoreceptor protection via blockade of BET epigenetic readers in a murine model of inherited retinal degeneration. J Neuroinflammation., 2017; 14(1): 14: 1-15.

9. Lobanova ES, Finkelstein S, Li J, Travis AM, Hao Y, Klingeborn M, Skiba NP, Deshaies RJ, Arshavsky VY, Increased proteasomal activity supports photoreceptor survival in inherited retinal degeneration. Nat Commun., 2018; 9(1): 1738: 1-11.

10. McLenachan S, Zhang D, Hao E, Zhang L, Chen SC, Human limbal neurospheres prevent photoreceptor cell death in a rat model of retinal degeneration. Clin Exp Ophthalmol., 2017; 45(6): 613-624.

11. Mehmood MH, Malik A, Akhtar MS, Haider G, Gilani AH, Antihyperglycaemic, antihyperlipidaemic and antihypertensive effect of a polyherbal formulation in alloxan-induced diabetic rats. Farmacia, 2020; 68(5): 882-890.

12. Jung E, Park SB, Jung WK, Kim HR, Kim J. Aucubin, An Active Ingredient in Aucuba japonica, Prevents N-methyl-N-nitrosourea-induced Retinal Degeneration in Mice. Molecules, 2019; 24(24): 4437: $1-10$.

13. Aplin FP, Luu CD, Vessey KA, Guymer RH, Shepherd RK, Fletcher EL, ATP-induced photoreceptor death in a feline model of retinal degeneration. Invest Ophthalmol Vis Sci., 2014; 55(12): 8319-8329.

14. Tonade D, Liu H, Palczewski K, Kern TS, Photoreceptor cells produce inflammatory products that contribute to retinal vascular permeability in a mouse model of diabetes. Diabetologia, 2017; 60(10): 2111-2120.

15. Dong K, Han L, Liu J, Wang F, Sun X, RNA Interference reveals the coregulatory effects of cylindromatosis on apoptosis and necroptosis of photoreceptor cells in experimental retinal detachment. Am J Pathol., 2017; 187(8): 1763-1771.

16. Tonade D, Liu H, Kern TS, Photoreceptor cells produce inflammatory mediators that contribute to endothelial cell death in diabetes. Invest Ophthalmol Vis Sci., 2016; 57(10): 4264-4271.

17. Murakami Y, Notomi S, Hisatomi T, Nakazawa T, Ishibashi T, Miller JW, Vavvas DG, Photoreceptor cell death and rescue in retinal detachment and degenerations. Prog Retin Eye Res., 2013; 37: 114-140.

18. Lv J, Xing Y, Down-regulation of Fra-2 alleviates light-induced retina damage by inhibiting the PARP1/AIF pathway. Int J Clin Exp Pathol., 2018; 11(8): 4221-4229. 